GRASAS Y ACEITES 65 (3)

July-September 2014, e029

ISSN-L: 0017-3495

doi: http://dx.doi.org/10.3989/gya.109213

\title{
Cold pressed poppy seed oils: sensory properties, aromatic profiles and consumer preferences
}

\author{
D.D. Emir ${ }^{\mathrm{a}}$, O. Güneşer ${ }^{\mathrm{a}}$ and E. Yilmaz ${ }^{\mathrm{a}, \bowtie}$ \\ ${ }^{a}$ Canakkale Onsekiz Mart University, Faculty of Engineering, \\ Department of Food Engineering, Terzioğlu Campus, 17020, Çanakkale/Turkey \\ Corresponding author: eyilmaz@comu.edu.tr
}

Submitted: 16 October 2013; Accepted: 27 January 2014

SUMMARY: The sensory descriptions, aromatic profiles and consumer preferences of poppy seed oils produced from three poppy varieties (ofis3, ofis4, and ofis8) by cold pressing were studied. Roasting and enzyme treatments were applied to the seeds prior to cold pressing. In addition, 75 different volatiles were quantified by GC-MS analysis. A flavor profile analysis was made with 9 panelists and 12 terms were identified for the description of the oil. The results shown that, only earthy term scores were different among the seed varieties, while treatments have caused differences in roasted, hazelnut, hay and sweet aromatic terms. Roasting and enzyme treatments decreased hay and increased sweet aromatic values. The enzyme treatment of the poppy seeds enhanced fermented and waxy scores in the cold press oils. 1-hexanol, 2-heptanone, 2-pentanone, 2-pentyl furan, 3-ethyl2-methyl 1,3-hexadiene, 2-(dimethylamino)-3-phenylbenzo[b]thiophene, 3-octen-2-one, 4-hydroxyphenylacetic acid, alpha-pinene, limonene, dimethyl sulfone, mercaptoacetic acid, hexanal and nonanal were quantified as the major volatiles in all treatment groups. Consumer test results indicated that roasted samples are more liked, and the yellow (ofis 4 ) roasted sample was identified as the most preferred $(53.55 \%)$ oil by consumers. This study provides the first sensory descriptive definitions and consumer preferences for poppy seed oils.

KEYWORDS: Cold Press; Consumer Acceptance; Flavor Profile Analysis; Poppy seed Oil; Roasting; Volatiles

RESUMEN: Aceites de semillas de amapola prensados en frio: Propiedades sensoriales, perfiles aromáticos y preferencias del consumidor. En este trabajo, se analizan las descripciones sensoriales, perfiles aromáticos y preferencias de los consumidores de aceites de semillas de amapola producidosmediante prensado en frío a partir de tres variedades (ofis3, ofis4, y ofis8).Previo al prensado en frío, a las semillas se aplicóuna fase de tostado y un tratamiento enzimático. Además del análisis GC-MS donde se cuantificaron 75 compuestos volátiles, el perfil del sabor,realizado con 9 panelistas,logra identificar 12 términos descriptores. Los resultados muestran que, solamente la puntuación del término "terroso" fue diferente entre las variedades de semillas, también los tratamientos provocan diferencias en los términos, tostado, avellana, heno y aromas dulces. El tostado y los tratamientos enzimáticos disminuyeron la puntuación de heno y aumentó los valores de aromático dulce. El tratamiento enzimático de las semillas de amapola mejora los valores de fermentado y cera en los aceites prensados en frío. Los principales compuestos volátiles cuantificados en todos los grupos y tratamientos fueron:1-hexanol, 2-heptanona , 2-pentanona, furano 2-pentilo, 3-etil-2-metil 1,3- hexadieno, 2-(dimetilamino)-3-fenilbenzo[b]tiofeno, 3-octen-2-one, ácido 4- hidroxifenilacético, alfa-pineno, limoneno, dimetilsulfona, ácido mercaptoacético, hexanal y nonanal. Los resultados de las pruebas de consumo indican que las muestras tostadas son las que más gusta, y el amarillo de la muestra tostada ofis4 fue identificado como el del aceite preferido por los consumidores $(53,55 \%)$. Este estudio proporciona las primeras definiciones descriptivas sensoriales y preferencias de los consumidores para los aceites de semillas de amapola.

PALABRAS CLAVE: Aceite de semillas de amapola; Aceptación del consumidor; Análisis del flavor; Presión en frio, Tostado; Volátiles 
Citation/Cómo citar este artículo: Emir DD, Güneşer O, Yilmaz E. 2014. Cold Pressed Poppy seed Oils: Sensory Properties, Aromatic Profiles and Consumer Preferences. Grasas Aceites 65 (3): e029. doi: http://dx.doi.org/10.3989/ gya.109213.

Copyright: (C) 2014 CSIC. This is an open-access article distributed under the terms of the Creative Commons Attribution-Non Commercial (by-nc) Spain 3.0 Licence.

\section{INTRODUCTION}

Poppy seed oil is recognized as a nutritious and delicious edible oil for direct human consumption while other uses have been indicated in medicinal applications and for oleochemical productions as paints, varnishes, and coatings (Bozan and Temelli, 2003; Özcan and Atalay, 2006). In the literature, solvent, supercritical fluid or press extracted poppy seed oils were studied for their general physical and chemical properties and fatty acid, sterol and tocopherol compositions (Bozan and Temelli, 2003; Erinç et al., 2009; Krist et al., 2005; Özcan and Atalay, 2006). Cold pressing has emerged as a simple, cheap and easy edible oil production technique without the requirement of refining. Its main drawback is its limited oil yield which can be overcome by subsequent solvent extraction of the oily meal after cold pressing and in order to enhance press oil yield some pre-treatments (dehulling, crushing, limited heating, steaming, wetting, enzyme applications etc.) can also be applied to the seeds. Hence, it would be expected that these treatments may cause some changes in the aromatic profile, sensory properties, and consumer perceptions of the oils. Cold press oils are chemical free, self-stable products and have their own natural flavor. In addition, they retain most of their bioactive components, enjoy a great consumer awareness and consumption of this oils is growing (Martinez et al., 2008; Sing and Bargale, 2000). It is of extreme importance for an edible oil to have acceptable sensory properties for consumer preference because the market success of oil is mostly determined by consumer sensory perception together with quality and price. The literature for virgin olive oil is filled with studies about sensory properties and aromatic compositions, as well as the effects of different agricultural, processing and storage factors (Aparicio et al., 1997; Boskou, 1996; Ögü̈tçü et al., 2008).

Sensory analyses can be combined with aromatic analysis and/or consumer tests to modify the properties of products for the optimal consumer satisfaction. Among others, quantitative descriptive analysis and flavor profiling are the most widely used tests for the sensory characterization of oils together with consumer tests to assess consumer needs (Öğ̈̈tçü and Yilmaz, 2009; Brühl and Matthäus, 2008).

In a study by Wei et al. (2012), cold pressed rapeseed oil samples were analyzed for volatile compounds to observe the effects of seed variety and different processing operations. It was found that thermal treatment and microwave radiation have significantly changed the aromatic profile of the samples. Unfortunately, there were limited studies on the sensory and aromatic properties of other cold press oils, except for virgin olive oil. An early study on the chemical composition of the volatile oil of poppy seeds was published in China by $\mathrm{Li}$ et al., (1990). They detected hexanal, 2-heptanone, heptenal, 3-octen-2-one and 2-pentylfuran. The same volatile compounds were observed by Krist et al. (2005) for gray, white and blue poppy seed oils. The researchers analyzed the volatile constituents of the poppy seed oils by solid-phase microextraction technique. Gray, white and blue poppy seed oils were extracted at room temperature $\left(20^{\circ} \mathrm{C}\right)$ while blue poppy seed oil was extracted from seeds that had been heated at $60{ }^{\circ} \mathrm{C}$ for 30 min by pressing afterwards at room temperature. One gray poppy seed sample was acquired from Hungary, and it was indicated that the sample had been stored since 1868 . There was neither laboratory scale cold press machine utilization nor other pre-treatments in that study. The same research group published another article about the detection of poppy seed oil adulteration with sunflower oil based on volatile and triacylglycerol composition (Krist et al., 2006). In the literature, there was no other published study about the volatile composition of different poppy seed varieties and the effects of different production techniques on the oil aromatics with sensory properties; furthermore, consumer preferences concerning poppy seed oils were not determined.

The objectives of the present study were to assess the effects of roasting and enzyme treatment on the volatile compositions and sensory properties of cold pressed oils of three different poppy seed varieties and to reveal consumer preferences of the poppy seed oils with the best sensory quality.

\section{MATERIALS AND METHODS}

\subsection{Materials}

In this study three different poppy seed varieties registered by the Turkish Grain Board (TMO) were used. Poppy seeds of Ofis 8 (white) produced in Ulubey / Uşak, Ofis 4 (yellow) produced in Şuhut / Afyon and Ofis 3 (blue) produced in Ulubey / Uşak were collected from local growers. All varieties 
were cultivated in the 2011 harvest season and were dried and cleaned for foreign materials. The poppy seeds were stored in cotton, cloth bags $(25 \mathrm{~kg})$ in cool and dry storage conditions during the study. Ferzim Hemicellulase $(60.000 \mathrm{U} / \mathrm{g}$ activity at 55-65 ${ }^{\circ} \mathrm{C}$ and $4.0-6.5 \mathrm{pH}$ value) and Alphamalt BK Quick Protease $\left(12 \mathrm{U} / \mathrm{g}\right.$ activity at $40-65^{\circ} \mathrm{C}$ and 4.5-6.0 pH value) were bought from local chemical suppliers. Commercial poppy seed oils from markets and stored poppy seed oil samples from local seed mills in the city of Afyon were collected as reference materials for the sensory panel. The internal standard solution for aromatic compound analysis was composed of $82 \mu \mathrm{g}$ of 2-methyl-2-heptanone and $5520 \mu \mathrm{g}$ 2-methyl valeric acid dissolved $1 \mathrm{~mL}$ methanol. All chemicals and standards were of analytical grade and purchased either from Merck (Darmstadt, Germany) or Sigma-Aldrich (St. Louis, USA).

\subsection{Preparation of the Poppy seeds and Cold Pressing}

Each poppy seed variety was divided into two control, two roasting and two enzyme treatment groups so that there were two equal portions for each treatment group in every variety and cold pressing was applied in duplicate. Before cold pressing, the pre-treatments were completed for every portion in each treatment group and variety. The appropriate moisture content for optimum oil yield was determined as $12 \%$ for poppy seeds in the pre-experiments with the lab scale cold press machine (Koçmaksan ESM 3710, İzmir, Turkey). The moisture contents were constantly measured and set at $12 \%$ by water conditioning before pressing. Water conditioning was achieved through equilibrium in hermetic plastic bottles by spraying the calculated amount of water on the seeds and storing at room temperature for $24 \mathrm{~h}$. The amount of the added water was calculated by:

$$
\mathrm{W}=[(\mathrm{A} / \mathrm{B}) \times \mathrm{C}]-\mathrm{C}
$$

Where, $\mathrm{W}$ indicates amount of the added water $(\mathrm{g})$, A indicates the dry matter content of the seeds $(\%)$, $\mathrm{B}$ indicates the goal dry matter content $(\%)$ of seeds, and $\mathrm{C}$ indicates the amount of the seeds $(\mathrm{g})$.

Roasting of the poppy seeds was carried out in a Luxell L $\times 3530$ type oven (Kumtel, Turkey) (1450 $\mathrm{W})$ at $150{ }^{\circ} \mathrm{C}$ for $30 \mathrm{~min}$. The seeds were put in metal plates of $2 \mathrm{~cm}$ in height. After reaching $150{ }^{\circ} \mathrm{C}$, they were mixed up in 10 min intervals for constant heat transfer. At the end of $30 \mathrm{~min}$, the seeds were left to cool to room temperature and moisture levels were measured. Then the moisture content was measured and corrected by water conditioning. Enzyme treatments of the poppy seeds were performed by incubating them in the enzyme solution at a 1:1 w/w (seed:enzyme) level. For this purpose,
$60 \mathrm{U} / \mathrm{g}$ seed hemicellulase were dissolved in $500 \mathrm{~mL}$ of $0.1 \mathrm{M} \mathrm{Na}_{2} \mathrm{PO}_{4}+0.1 \mathrm{M}$ citric acid buffer solution ( $\mathrm{pH}$ 6.0). Due to the too small seed size of poppy, the enzyme solution was mixed with the seeds without crushing, and incubated at $60^{\circ} \mathrm{C}$ for 3 hours in a dry oven (Ecocell drying oven, MMM Med Center, Germany). Then $0.012 \mathrm{U} / \mathrm{g}$ seed protease were dissolved in $100 \mathrm{~mL}$ of the same buffer, added to the seed slurry, and incubated for an additional hour. After incubation, enzyme inactivation was accomplished by heating the seeds up to $100{ }^{\circ} \mathrm{C}$ and waiting for 2 hours at the same temperature to ensure seed drying as well. During the heat treatment, water vaporized although roasting had not occurred. Meanwhile, seed moisture levels were monitored and when they decreased down to $12 \%$, the batches were cooled to room temperature.

Cold pressing was carried out with a laboratory scale $\left(12 \mathrm{~kg}\right.$ seed $\cdot \mathrm{h}^{-1}$ capacity) cold press machine (Koçmaksan ESM 3710, İzmir, Turkey) which is a single head expeller type (kms10) with a $1.5 \mathrm{kw}$ powered engine and $0.6 \mathrm{kw}$ heating resistance. The $10 \mathrm{~mm}$ exit die, $20 \mathrm{rpm}$ screw rotation speed and $40{ }^{\circ} \mathrm{C}$ exit temperature were selected as constant parameters. When oil and meal were collected and weighed, the oil filtered immediately through a $40 \mu \mathrm{m}$ screen to separate suspended materials. Then it was put into amber colored, capped glass bottles, flushed with nitrogen, kept in a dark and cool place for 15 days for natural precipitation where plant remaining and phase separation of water took place. After decantation, the separated clear oil phases were collected and stored in the fridge during the analyses.

\subsection{Flavor Profile Analysis of the Poppy seed Oils}

A sensory description of the poppy seed oils was made by Flavor Profile Analysis (FPA) (Meilgard et al., 1991) with a flavor panel evaluation using the vegetable oils method of Cg 2-83 (AOCS, 1984) and other literature (Brühl and Matthäus, 2008; Ögütçü et al., 2008; Lyon and Watson, 1994) which was used for the FPA method development of the samples. Nine panelists (5 female, 4 male, aged 28-42) took part voluntarily in the flavor profile analysis and panelist training was completed for 15 hours with 3 separate sessions on different days. During these sessions, under the moderation of a panel leader, the panelists developed the sensory descriptive terms by using different fresh and stored poppy seed oil samples collected from marketplaces. The standards used to calibrate the panelists and the developed descriptive terms by the panel are shown in Table 1 . FPA was carried out using a 5-point scale (0-none to 4-maximum intensity) ballot anchored with each point on it. Within each panel, 3 oil samples were coded with 3 -digit numbers, put into a colorless round bottom glass with a narrower head and closed 
TABLE 1. Descriptive Terms with References Used for the Flavor Profile Analysis of the Poppy seed Oils

\begin{tabular}{lc}
\hline Descriptive Term & Reference Standard \\
\hline Poppy seed-like & Poppy paste \\
Roasted & Roasted bread \\
Hazelnut-like & Hazelnut \\
Hay & Dry hay \\
Astringent & Alum solution $(\% 0.1)$ \\
Waxy & Melted paraffin \\
Fermented & Wet yeast \\
Spicy & Pepper, clove, peppermint mixture \\
Earthy & Humid soil \\
Bitter & Caffeine solution $(\% 0.05)$ \\
Sweet aromatic & Flower Honey \\
Throatcatching & Harsh taste after 30 seconds when swallowed \\
\hline
\end{tabular}

with a metal lid. The poppy seed oil samples were served to the panelists at room temperature under daylight, along with water, a slice of apple and an expectoration cup for the participants to clean their palate between samples. Duplicate samples were served in different sessions in a randomized order for each of the two production samples.

\subsection{Identification and Quantification of Volatile Compounds}

The volatile compounds in the poppy seed oils were analyzed according to the technique of Krist et al., (2005) with minor modifications. Extractions of the volatile compounds were achieved by the solid phase micro-extraction (SPME) technique (Pawliszyn, 2012). For this purpose, $5 \mathrm{~mL}$ of oil sample were weighed into a $40 \mathrm{~mL}$ amber SPME vial (Supelco, Bellfonte, USA) and $1 \mathrm{~g}$ of $\mathrm{NaCl}$ and $10 \mu \mathrm{L}$ internal standard $(0.1 \mu \mathrm{L}$ of 2-methyl3-heptanone and $6 \mu \mathrm{L}$ of 2 methyl valeric acid dissolved in $1 \mathrm{~mL}$ methanol) were added. The closed vial was vortexed for $1 \mathrm{~min}$. Then, the vial was placed in a water bath (GFL, Germany) constant at $40{ }^{\circ} \mathrm{C}$ for $20 \mathrm{~min}$ to equlibrate the volatiles in the headspace. Then, an SPME (2 cm to $50 / 30$ um DVB / Carboxen / PDMS, Supelco, Bellafonte) needle was inserted into the vial. The SPME fiber was exposed at a depth of $2 \mathrm{~cm}$ in the headspace of the vial for $20 \mathrm{~min}$ at $40{ }^{\circ} \mathrm{C}$ in a waterbath. Then, the fiber-collected volatiles were injected into a GC/MS (Agilent 6890N/Agilent 5875C mass spectrometer, Agilent technologies, Wilmington, DE, USA), immediately. A nonpolar HP5 MS column $(30-\mathrm{m} \times 0.25-\mathrm{mm}$ i.d. $\times 0.25-\mu \mathrm{m}$ film thickness, $\mathrm{J} \& \mathrm{~W}$ Scientific, Folsom, CA) was used for separation of the volatile compounds. The $\mathrm{GC}$ oven temperature was programmed $38^{\circ} \mathrm{C}$ for $1 \mathrm{~min}$., and 40 to $220^{\circ} \mathrm{C}$ at $5{ }^{\circ} \mathrm{C} \cdot \mathrm{min}^{-1}$. The final oven temperature was held for $20 \mathrm{~min}$. Helium was used as a carrier gas at 1.2 $\mathrm{mL} \cdot \mathrm{min}^{-1}$. The MSD conditions were as follows: capillary direct interface temperature, $280{ }^{\circ} \mathrm{C}$; ionization energy, $70 \mathrm{eV}$; mass range, 35 to $350 \mathrm{amu}$; scan rate, 4.45 scans/s. Identification of the volatiles was based on the comparison of the mass spectra of unknown compounds with those in the National Institute of Standards and Technology (NIST, 2008) and Wiley Registry of Mass Spectral Data, 7th Edition databases (WILEY, 2005). Quantification of the volatile compounds was positively calculated from the relative abundance of volatile compounds using the Equation given below (Avşar et al., 2004). Methyl pentanoic acid and 2-methyl-3-heptanone were used as an internal standard (IS) for acidic and neutral-basic character compounds, respectively.

Mean relative abundance $\left(\mathrm{ng} \cdot \mathrm{kg}^{-1}\right)=$ concentration of IS $\times$ peak area of compound / peak area of the IS. (Eq. 2).

\subsection{Consumer Acceptance Test of the Poppy seed Oils}

Sensory attributes (appearance, color, odor and taste) of the poppy seed oils were assessed by a 5 -point hedonic scale ( 1 for "dislike extremely" to 5 for "like extremely"). Triple sets (control, roasted and enzyme treated) of each poppy seed variety (ofis8, ofis3 and ofis4) were prepared separately and each group was tested twice by 50 volunteer consumers (faculty, staff and students in the university) on different days. The mean scores of the collected hedonic scales were calculated and one sample from each variety was selected based on the highest hedonic scores of the consumers. Then 3 selected poppy seed oil samples (ofis3-roasted, ofis4-roasted and ofis8-enzyme) were coded with a 3-digit number, served to 150 different consumers in a glass and only one question was asked: 'Please examine the coded oil samples visually, then smell each one and finally take one spoon, spread the oil in your mouth and swallow it. Circle the code number of the one which you would like most'. The collected data were used to calculate the percentage of consumer preference for each sample.

\subsection{Statistical Analysis}

Sensory analysis and consumer acceptance test data were applied to the non-parametric KruskalWallis test. Dunn's test was used for mean separation. Nonmetric Multidimensional Scale (MDS) analysis was used to observe the complex relationships among the 12 sensory descriptive terms measured by the panel and 75 volatile compounds determined with GC-MS analysis (Sheskin, 2004). Statistical analyses were completed by using Minitab ver. 16.1.1 (MINITAB, 2010) and SPSS package programs (SPSS, 1994). For all statistical analyses, the level of confidence was at least $95 \%$ in this study. 


\section{RESULTS AND DISCUSSION}

In this study, poppy seed oils extracted from three seed varieties (ofis3, ofis 4 and ofis8) by the cold press technique with previous pre-treatments (roasted or enzyme treated against a control) were characterized by 12 different descriptive terms (Table 1) by panelists in FPA.

Sensory terms and their measured mean values for the poppy seed oils are shown in Table 2. It was observed that there were no statistically significant differences among the seed varieties in terms of poppy seeds $(\mathrm{P}=0.347)$, roasted $(\mathrm{P}=0.707)$, hazelnut $(\mathrm{P}=0.735)$, hay $(\mathrm{P}=0.606)$, astringent $(\mathrm{P}=0.685)$, waxy $(\mathrm{P}=0.277)$, fermented $(\mathrm{P}=0.236)$, spicy $(\mathrm{P}=0.868)$, bitter $(\mathrm{P}=0.115)$, sweet aromatic $(\mathrm{P}=0.343)$ and throat catching $(\mathrm{P}=0.342)$ terms. However, earthy flavor $(\mathrm{P}=0.038)$ was different among the varieties. The Ofis8 (white) poppy seed variety had a more earthy flavor than the other varieties. These results have indicated that genetic differences among the seeds are not a determining factor for the sensory definitions of the produced oils. Hence, the oils extracted from the ofis3, ofis 4 and ofis8 varieties can substitute for each other as consumer sale products. Also, it is clear from the results that the most important sensory descriptive terms for poppy seed oils are poppy seed, roasted, hazelnut, earthy and waxy as evidenced from the relatively higher scores (Table 2) that are recorded. In most samples, bitter, astringent and fermented scores are low, and this determination is very important for the consumer acceptance of edible

TABle 2. Panel Measured Sensory Descriptive Properties of the Poppy seed Oil Samples (0: none to 4:maximum)*

\begin{tabular}{|c|c|c|c|c|c|}
\hline \multirow[b]{2}{*}{ Sensory property } & \multirow[b]{2}{*}{ Treatment } & \multicolumn{4}{|c|}{ Poppy seed Variety } \\
\hline & & Ofis 8 (white) & Ofis 3 (blue) & Ofis 4 (yellow) & Total $(\mathrm{P}=0.726)$ \\
\hline \multirow{4}{*}{ Poppy seed } & Control & $2.65 \pm 0.15$ & $2.65 \pm 0.35$ & $2.70 \pm 0.00$ & $2.66 \pm 0.09$ \\
\hline & Roasted & $2.95 \pm 0.25$ & $2.65 \pm 0.15$ & $2.80 \pm 0.20$ & $2.80 \pm 0.10$ \\
\hline & Enzyme & $2.90 \pm 0.10$ & $2.65 \pm 0.05$ & $2.55 \pm 0.05$ & $2.70 \pm 0.07$ \\
\hline & Total $(\mathrm{P}=0.347)$ & $2.83 \pm 0.09$ & $2.65 \pm 0.09$ & $2.68 \pm 0.07$ & \\
\hline \multirow{5}{*}{ Roasted } & & & & & Total $(\mathrm{P}=0.012)$ \\
\hline & Control & $1.90 \pm 0.20$ & $1.95 \pm 0.15$ & $2.05 \pm 0.05$ & $1.96 \pm 0.07^{\mathrm{A}}$ \\
\hline & Roasted & $2.70 \pm 0.10$ & $2.20 \pm 0.20$ & $2.60 \pm 0.20$ & $2.50 \pm 0.12^{\mathrm{B}}$ \\
\hline & Enzyme & $2.85 \pm 0.35$ & $2.85 \pm 0.35$ & $2.35 \pm 0.25$ & $2.68 \pm 0.17^{\mathrm{B}}$ \\
\hline & Total $(\mathrm{P}=0.707)$ & $2.48 \pm 0.21$ & $2.33 \pm 0.20$ & $2.33 \pm 0.13$ & \\
\hline \multirow{5}{*}{ Hazelnut } & & & & & Total $(\mathrm{P}=0.032)$ \\
\hline & Control & $2.30 \pm 0.00$ & $2.25 \pm 0.15$ & $2.25 \pm 0.15$ & $2.26 \pm 0.05^{\mathrm{B}}$ \\
\hline & Roasted & $2.55 \pm 0.15$ & $2.40 \pm 0.00$ & $2.75 \pm 0.05$ & $2.56 \pm 0.07^{\mathrm{A}}$ \\
\hline & Enzyme & $2.20 \pm 0.20$ & $2.40 \pm 0.00$ & $2.35 \pm 0.05$ & $2.31 \pm 0.06^{\mathrm{B}}$ \\
\hline & Total $(\mathrm{P}=0.735)$ & $2.35 \pm 0.09$ & $2.35 \pm 0.05$ & $2.45 \pm 0.10$ & \\
\hline \multirow{5}{*}{ Hay } & & & & & Total $(\mathrm{P}=0.045)$ \\
\hline & Control & $1.40 \pm 0.10$ & $1.60 \pm 0.10$ & $1.50 \pm 0.10$ & $1.50 \pm 0.05^{\mathrm{A}}$ \\
\hline & Roasted & $1.40 \pm 0.00$ & $0.75 \pm 0.05$ & $1.20 \pm 0.20$ & $1.12 \pm 0.13^{\mathrm{B}}$ \\
\hline & Enzyme & $1.35 \pm 0.05$ & $1.25 \pm 0.05$ & $1.40 \pm 0.00$ & $1.33 \pm 0.03^{\mathrm{AB}}$ \\
\hline & Total $(\mathrm{P}=0.606)$ & $1.38 \pm 0.03$ & $1.20 \pm 0.15$ & $1.36 \pm 0.08$ & \\
\hline \multirow{5}{*}{ Astringent } & & & & & Total $(\mathrm{P}=0.121)$ \\
\hline & Control & $1.05 \pm 0.05$ & $1.00 \pm 0.20$ & $1.35 \pm 0.35$ & $1.13 \pm 0.13$ \\
\hline & Roasted & $0.90 \pm 0.20$ & $1.05 \pm 0.05$ & $0.90 \pm 0.10$ & $0.95 \pm 0.06$ \\
\hline & Enzyme & $1.40 \pm 0.10$ & $1.50 \pm 0.00$ & $0.95 \pm 0.25$ & $1.28 \pm 0.12$ \\
\hline & Total $(\mathrm{P}=0.685)$ & $1.11 \pm 0.11$ & $1.18 \pm 0.11$ & $1.06 \pm 0.14$ & \\
\hline \multirow{5}{*}{ Waxy } & & & & & Total $(\mathrm{P}=0.192)$ \\
\hline & Control & $1.50 \pm 0.10$ & $1.35 \pm 0.15$ & $1.35 \pm 0.05$ & $1.40 \pm 0.05$ \\
\hline & Roasted & $1.45 \pm 0.25$ & $1.15 \pm 0.15$ & $1.30 \pm 0.20$ & $1.30 \pm 0.10$ \\
\hline & Enzyme & $1.65 \pm 0.15$ & $1.85 \pm 0.25$ & $1.30 \pm 0.00$ & $1.60 \pm 0.12$ \\
\hline & Total $(\mathrm{P}=0.277)$ & $1.53 \pm 0.08$ & $1.45 \pm 0.18$ & $1.31 \pm 0.05$ & \\
\hline
\end{tabular}


TABLE 2 (Continued)

\begin{tabular}{|c|c|c|c|c|c|}
\hline \multirow[b]{2}{*}{ Sensory property } & \multirow[b]{2}{*}{ Treatment } & \multicolumn{4}{|c|}{ Poppy seed Variety } \\
\hline & & Ofis 8 (white) & Ofis 3 (blue) & Ofis 4 (yellow) & Total $(P=0.726)$ \\
\hline \multirow{5}{*}{ Fermented } & & & & & Total $(\mathrm{P}=0.209)$ \\
\hline & Control & $1.35 \pm 0.15$ & $0.95 \pm 0.25$ & $1.25 \pm 0.25$ & $1.18 \pm 0.12$ \\
\hline & Roasted & $1.05 \pm 0.25$ & $1.20 \pm 0.10$ & $0.95 \pm 0.15$ & $1.06 \pm 0.09$ \\
\hline & Enzyme & $1.60 \pm 0.10$ & $1.75 \pm 0.05$ & $1.00 \pm 0.00$ & $1.45 \pm 0.14$ \\
\hline & Total $(\mathrm{P}=0.236)$ & $1.33 \pm 0.12$ & $1.30 \pm 0.16$ & $1.06 \pm 0.09$ & \\
\hline \multirow{5}{*}{ Spicy } & & & & & Total $(\mathrm{P}=0.374)$ \\
\hline & Control & $0.85 \pm 0.15$ & $0.95 \pm 0.25$ & $1.10 \pm 0.00$ & $0.96 \pm 0.08$ \\
\hline & Roasted & $1.15 \pm 0.05$ & $0.85 \pm 0.15$ & $1.00 \pm 0.20$ & $1.00 \pm 0.08$ \\
\hline & Enzyme & $1.30 \pm 0.20$ & $1.20 \pm 0.00$ & $1.00 \pm 0.00$ & $1.16 \pm 0.07$ \\
\hline & Total $(\mathrm{P}=0.868)$ & $1.10 \pm 0.10$ & $1.00 \pm 0.10$ & $1.03 \pm 0.05$ & \\
\hline \multirow{5}{*}{ Earthy } & & & & & Total $(\mathrm{P}=0.132)$ \\
\hline & Control & $2.00 \pm 0.40$ & $1.25 \pm 0.15$ & $1.35 \pm 0.05$ & $1.53 \pm 0.18$ \\
\hline & Roasted & $1.45 \pm 0.05$ & $0.70 \pm 0.10$ & $1.00 \pm 0.20$ & $1.05 \pm 0.15$ \\
\hline & Enzyme & $1.25 \pm 0.25$ & $1.15 \pm 0.05$ & $0.90 \pm 0.30$ & $1.10 \pm 0.12$ \\
\hline & Total $(\mathrm{P}=0.038)$ & $1.56 \pm 0.18^{\mathrm{a}}$ & $1.03 \pm 0.11^{\mathrm{b}}$ & $1.08 \pm 0.12^{\mathrm{b}}$ & \\
\hline \multirow{5}{*}{ Bitter } & & & & & Total $(\mathrm{P}=0.088)$ \\
\hline & Control & $1.35 \pm 0.05$ & $0.90 \pm 0.10$ & $1.40 \pm 0.20$ & $1.21 \pm 0.11$ \\
\hline & Roasted & $1.10 \pm 0.00$ & $0.35 \pm 0.15$ & $0.80 \pm 0.20$ & $0.75 \pm 0.15$ \\
\hline & Enzyme & $1.45 \pm 0.05$ & $1.30 \pm 0.20$ & $0.80 \pm 0.20$ & $1.18 \pm 0.14$ \\
\hline & Total $(\mathrm{P}=0.155)$ & $1.30 \pm 0.06$ & $0.85 \pm 0.18$ & $1.00 \pm 0.15$ & \\
\hline \multirow{5}{*}{ Sweet aromatic } & & & & & Total $(\mathrm{P}=0.033)$ \\
\hline & Control & $0.80 \pm 0.00$ & $0.65 \pm 0.05$ & $0.90 \pm 0.10$ & $0.78 \pm 0.05^{\mathrm{B}}$ \\
\hline & Roasted & $1.20 \pm 0.00$ & $1.20 \pm 0.20$ & $1.15 \pm 0.05$ & $1.18 \pm 0.05^{\mathrm{A}}$ \\
\hline & Enzyme & $0.70 \pm 0.10$ & $1.20 \pm 0.00$ & $1.40 \pm 0.10$ & $1.10 \pm 0.13^{\mathrm{A}}$ \\
\hline & Total $(\mathrm{P}=0.343)$ & $0.90 \pm 0.10$ & $1.01 \pm 0.12$ & $1.15 \pm 0.09$ & \\
\hline \multirow{5}{*}{ Throat catching } & & & & & Total $(\mathrm{P}=0.133)$ \\
\hline & Control & $1.65 \pm 0.35$ & $1.45 \pm 0.15$ & $1.70 \pm 0.70$ & $1.60 \pm 0.21$ \\
\hline & Roasted & $1.15 \pm 0.05$ & $0.90 \pm 0.20$ & $1.20 \pm 0.00$ & $1.08 \pm 0.07$ \\
\hline & Enzyme & $1.90 \pm 0.30$ & $1.30 \pm 0.20$ & $0.90 \pm 0.30$ & $1.36 \pm 0.22$ \\
\hline & Total $(\mathrm{P}=0.342)$ & $1.56 \pm 0.18$ & $1.21 \pm 0.13$ & $1.26 \pm 0.24$ & \\
\hline
\end{tabular}

*The values are given as mean \pm standard error. There were 9 samples per treatment and variety with 2 replicates for each sample. ${ }^{\mathbf{A}-\mathbf{B}}$ Means followed by different superscript letters represent significant differences in the treatments for sensory property. ${ }^{\mathrm{a}-\mathrm{b}}$ Means followed by different superscript letters represent significant differences in the poppy seed variety for sensory property.

oils. In a similar manner, when the effects of treatments (control, roasted and enzyme) on the sensory properties of poppy seed oils were taken into consideration, no significant differences were determined between the treatments for poppy seed $(\mathrm{P}=0.726)$, astringent $(\mathrm{P}=0.121)$, waxy $(\mathrm{P}=0.192)$, fermented $(\mathrm{P}=0.209)$, spicy $(\mathrm{P}=0.374)$, earthy $(\mathrm{P}=0.132)$, bitter $(\mathrm{P}=0.088)$ and throat catching $(\mathrm{P}=0.133)$ terms. On the other hand, there were significant differences between the treatments for roasted $(\mathrm{P}=0.012)$, hazelnut $(\mathrm{P}=0.032)$, hay $(\mathrm{P}=0.045)$ and sweet aromatic terms $(\mathrm{P}=0.033)$. These results were rather expected, since roasting may have caused Maillard reactions so that aromatics associated with roasted flavor were formed (Krist et al., 2005). While sensory hay scores were reduced by roasting and enzyme treatments, sweet aromatic values were enhanced by both treatments. In general, it can be said that seed roasting has improved the positive sensory properties for the poppy seed oils, while enzyme treatment has caused some minor increases in the waxy and fermented flavors, which are perceived as negative attributes in edible oils (Öğütçü et al., 2008; Brühl and Matthäus, 2008). 
The volatile compound compositions of the oil samples were analyzed by SPME-GC/MS measurements. Seventy-five different volatiles were determined in the samples and are shown in Table 3. The volatiles determined in most of the samples were 1-hexenol, 1-octen-3-ol, 1-pentenol, $\gamma$-butyrolactone, $\gamma$-nonalactone, $\gamma$-octalactone, 2-heptanone, 2-nonanone, 2-pentanone, 3-ethyl-2-methyl-1,3-hexadiene, $\alpha$-pinene, limonene, mercaptoacetic acid, naphthalene, decanal, heptanal, hexanal and caprylic acid. When Table 3 is viewed critically, it can be observed that the volatiles of 1-hexanol, 2-heptanone, 2-pentanone, 2-pentylfuran, 3-ethyl-2-methyl, 1,3-hexadiene, 2-(dimethylamino)-3-phenylbenzo[b] thiophene, 3-octen-2-one, 4-hydroxyphenylacetic acid, $\alpha$-pinene, limonene, dimethyl sulfone, hexanal and nonanal were determined in all treatment groups. In general, poppy seed oils are characterized by aromatics described with fatty, creamy, nutty, roasted, sweet, fruity, waxy, woody, citrus and similar definitions. Hence, it could be said that these oils are very aromatic and rich flavored specialty oils. On the other hand, 4-ethyl benzealdehyde, 2-methyl5-pyrazine, 2,3-dimethyl-5-ethylpyrazine, 2,4-nonadienal, 2-ethyl-3,5-dimethyl pyrazine and dimethyl sulfoxide were found only in the roasted samples, but not in the control or the enzyme treated samples. The aroma/flavor descriptions of these volatiles indicate roasted, cooked, caramel, biting, nutty and similar definitions and are in good agreement with the processes applied to the samples.

These volatiles are usually formed by heat treatment in processed foods like cheese, biscuits, roasted nuts, roasted beef etc. and attributed in a positive manner in terms of consumer acceptance (Krist et al., 2005). Similarly, 2-methyl propanal and benzaldehyde-phenylmethanal are determined only in the enzyme treated samples. Ethanol is the single one detected only in the control but not roasted or enzyme treated samples. Compared to the study of Krist et al., (2005) more volatile aromatic substances have been identified in this study and this result may be related to the different pre-treatments applied before cold pressing. The 30 different volatile compounds listed by Krist et al., (2005) were identified with high amounts in our samples, although camphene, pentanal, butane-2,3-diol, and hexalactone were not identified. As expected, other lactones and pentanol that are identified in the aromatic profile in this study are similar because of the same biomaterials.

The multiple relationships among the 12 sensory descriptive terms and 75 different volatile compounds of the samples can be visualized simultaneously by a technique called multidimensional scaling (MDS) which provides a closeness map in dimensions. Since the data are composed of both nominal and ordinal scale numbers and showed large variations, a standard deviation of 1 was applied prior to the MDS technique. In this statistical technique, the validity of the closeness map is defined by the stress value, and states that a stress value under 0.025 indicates very good; $0.025-0.05$ indicates good; $0.05-0.1$ indicates acceptable and $0.1-0.20$ indicates poor data separation. Figure 1 shows 4 different MDS maps produced from the data. The relationship of the sensory descriptive terms and measured volatiles only in the control samples is shown in Fig. 1 (a). There was no clear group formation but some closeness can be observed. In the control samples, the sensory terms of waxy, fermented, poppy seed, hazelnut and hay were distributed separately from each other and from the volatile compounds. Similarly $\alpha$-pinene was located away from all the other volatiles. Astringent and spicy descriptors, and mercaptoacetic acid (cn56) and pentanoic acid (cn73) were located closely.

The aroma/flavor descriptors and sensory terms are quite related. Similarly, bitter is in close proximity with 4-hydroxyphenylacetic acid (cn41), benzyl alcohol (cn47) and (S)- $\Delta$-caprolactone (cn23). In fact, these volatiles are mostly defined as sweet and floral, and not to be found related with the bitter definition. 2-Heptanone (cn20) and 3-octen-2one (cn39) were closer to the throatcatching term so these aromatics were defined with fatty, creamy and similar notes. Earthy and roasted terms, $\gamma$-pentalactone (cn8) and n-hexanal (cn64) were also closer in the control samples with no known aromatic definition relationship. The MDS map of only the roasted samples is shown in Fig. 1 (b). The sensory term hazelnut is separated from all others and located far from the volatile compounds. This is an unexpected result since several of the pyrazines are known to yield nutty flavors. But in our study variations among the aromatic measurements were larger and small differences in sensory attributes may not have been perceived by the panel. The sensory terms hay, bitter, sweet aromatic, earthy and waxy were somewhat closer to each other and to the volatiles of 2-(dimethylamino)3-phenylbenzo[b]thiophene (cn35), 1-hexenol (cn3), 1-pentanol (cn5), 2,5-dimethyl pyrazine (cn16), 3-methyl butanal (cn36) and (S)-deltacaprolactone (cn23). Similarly astringent, roasted, spicy and poppy seed terms and hexanal (cn64), 2-nonanone (cn27), 2,3-butanediol (cn12) and mercaptoacetic acid (cn56) were located closer to each other. Lastly, in these roasted samples, throat catching was closer to decanal (cn61), heptanal (cn62), 2,4-nonadienal (cn15), 3-ethyl-2,5 dimethyl pyrazine $(\mathrm{cn} 32)$ and 2-pentanone $(\mathrm{cn} 30)$. In Fig. 1 (c), the MDS map of the only enzyme treated samples is shown. Poppy seed and earthy terms were located far away from each other and from all others. Hazelnut and roasted terms were closer to each other but not closer to any volatile compounds on the map. Fermented and throat catching 


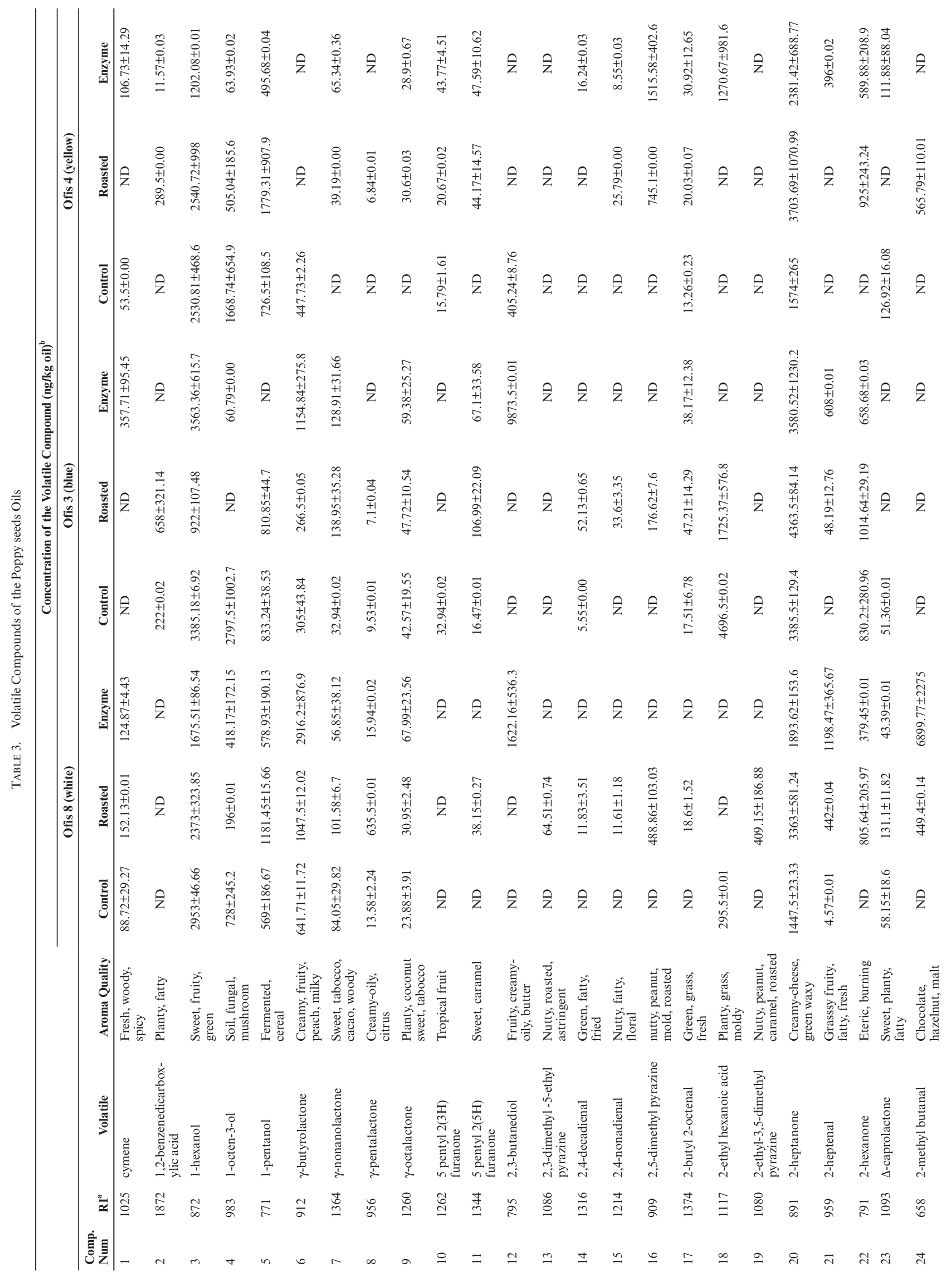




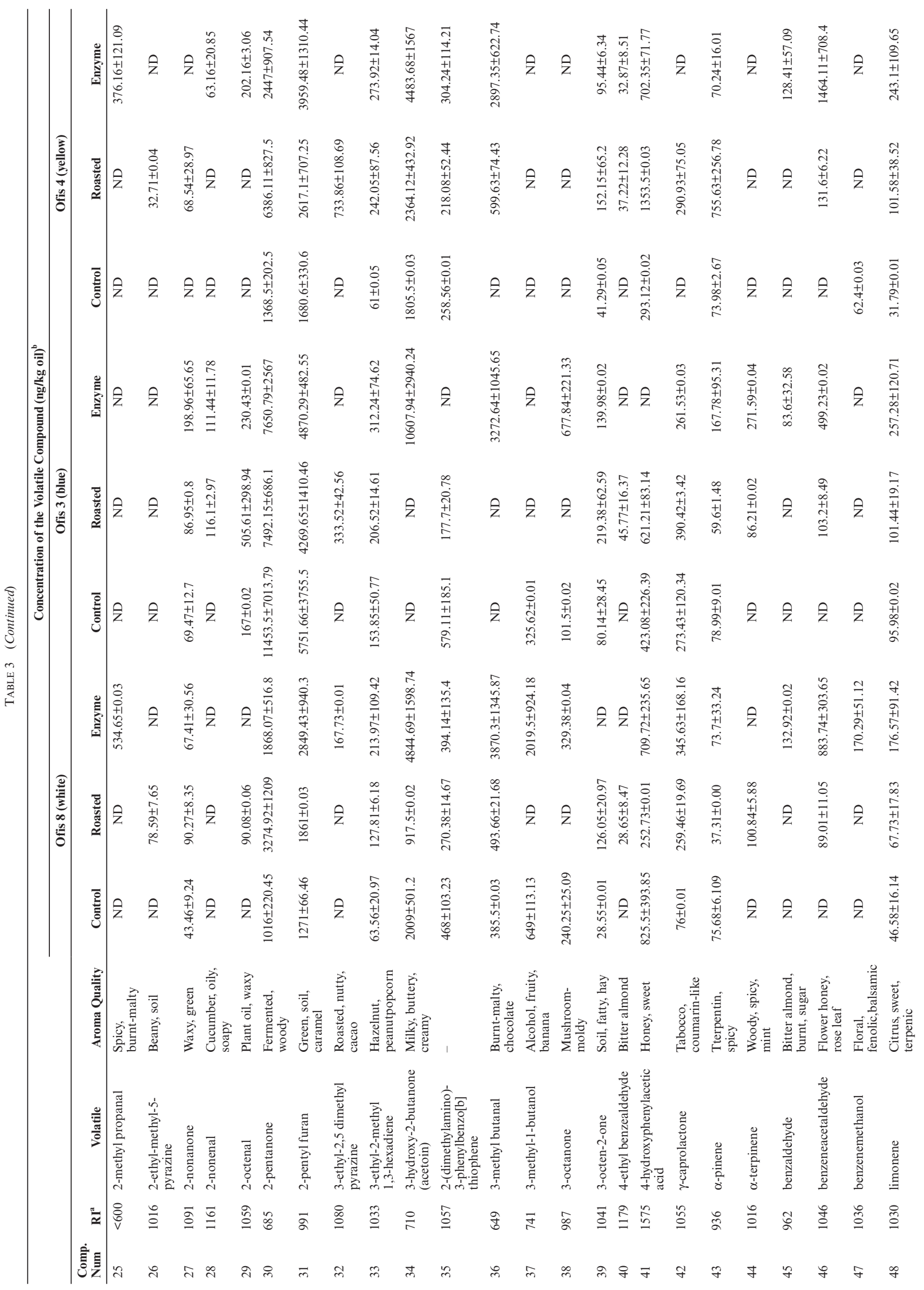




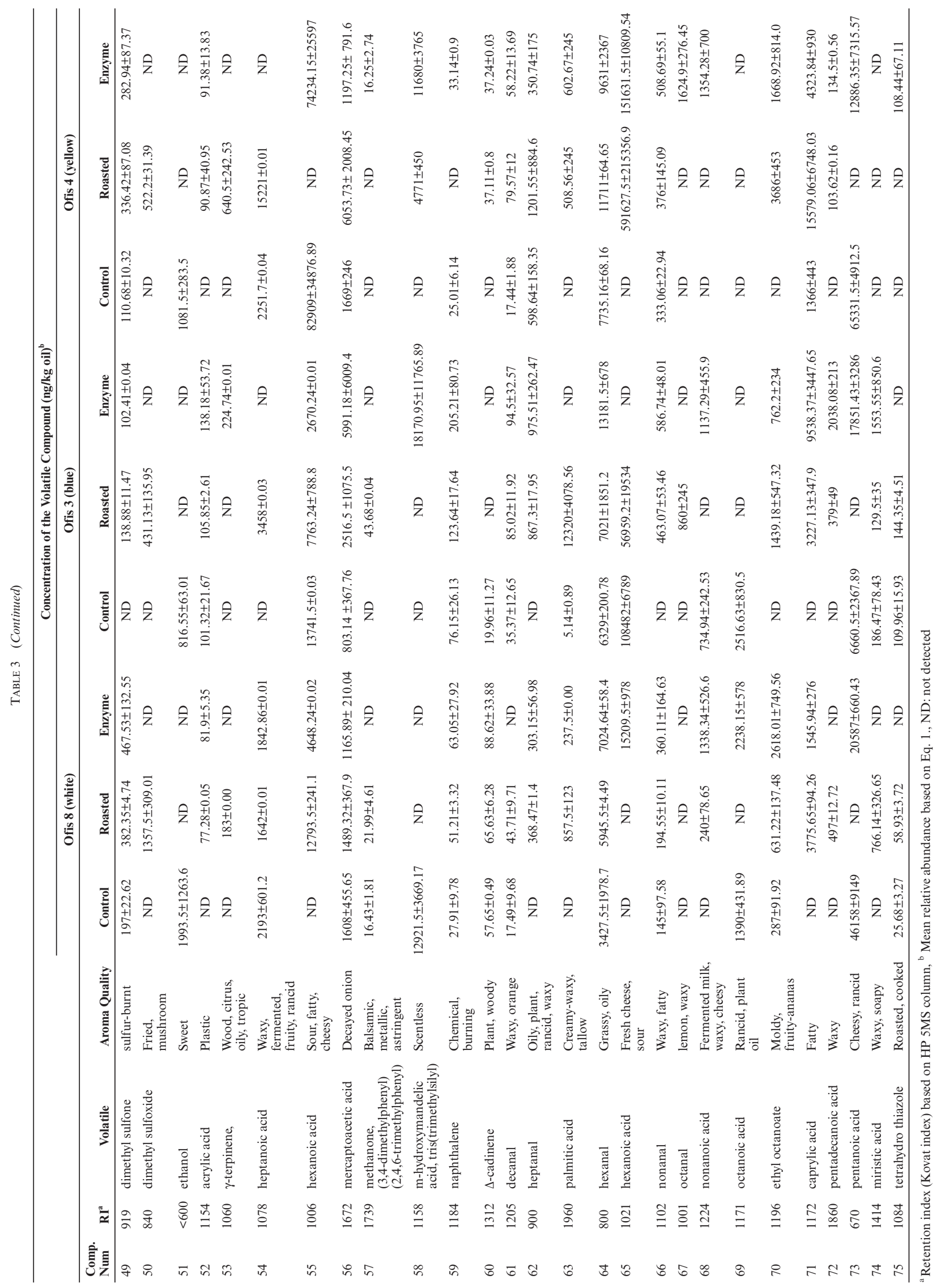



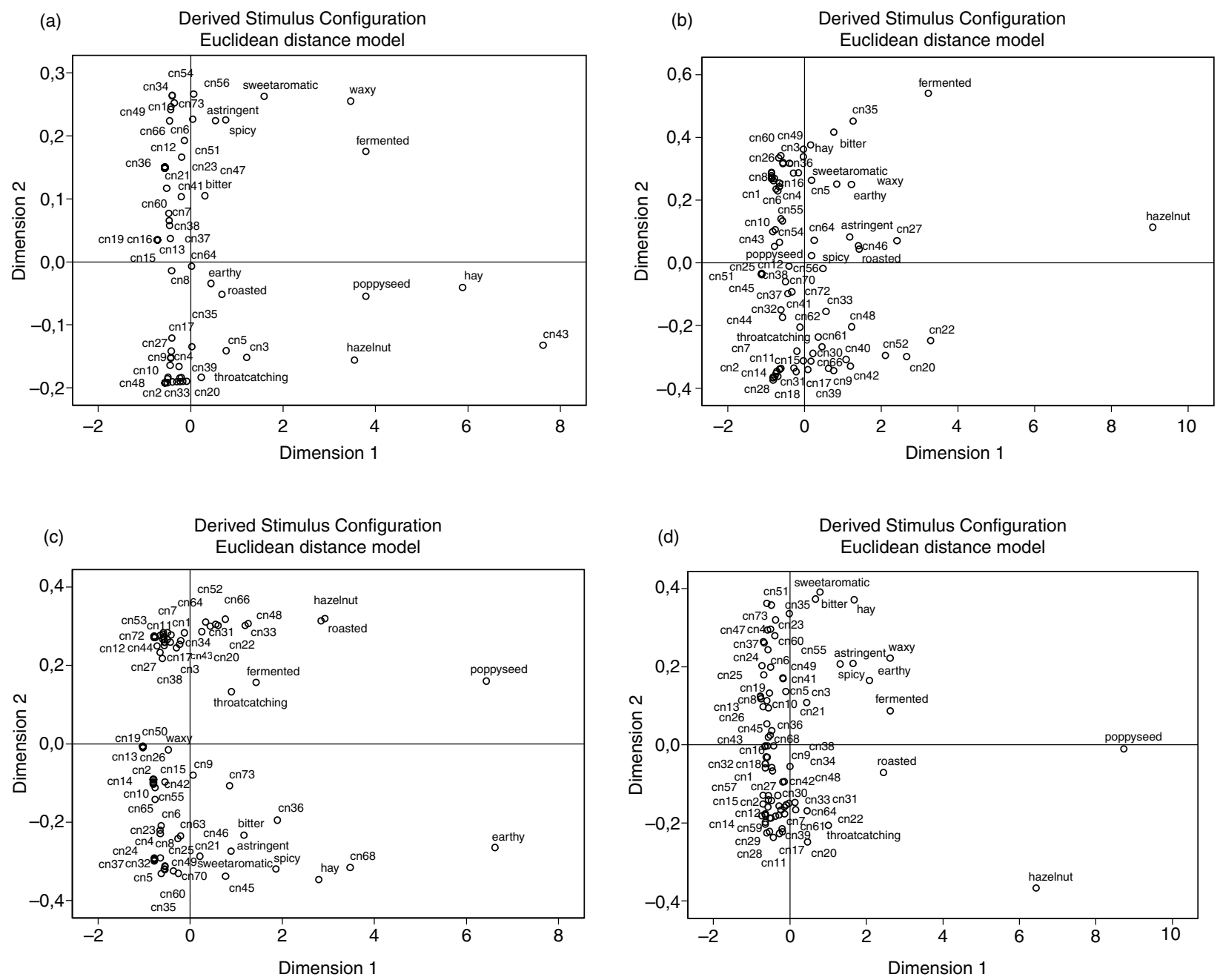

Figure 1. Geometric Representation of Volatile Compounds and Sensory Properties in (a) Control Samples (Stress $=0.02370$; $\mathrm{RSQ}=0.99921$ ), (b) Roasted Samples (Stress=0.04813; RSQ=0.99598), (c) Enzyme Treated Samples (Stress=0.03811; $\mathrm{RSQ}=0.99753$ ), and (d) All Samples Together (Stress $=0.05593 ; \mathrm{RSQ}=0.99567$ ) (Abbreviations: cn1-cn75; compounds from 1 to 75 listed in Table 2)

terms were closer to 1-hexenol (cn3), 2-heptenone (cn20) and 3-octanone (cn38) while waxy term and dimethyl sulfoxide (cn50), 2-ethyl-3,5-dimethyl pyrazine (cn19), 2-methyl-5-pyrazine (cn26) and $\gamma$-octalactone (cn9) were located nearby. Bitter, astringent and sweet aromatic were somewhat closer to each other and to 3-methyl butanal (cn36), benzaldehyde-phenylmethanal (cn45), 2-heptanal (cn21), benzeneacetaldehyde (cn46). Here the sensory definitions of the compounds are related to the sensory terms. It seems that the term hay is closer to nonanoic acid (cn68) in these samples. Lastly, in Fig. 1 (d), all the samples are analyzed together for MDS proximities. Consequently, the terms poppy seed, hazelnut, roasted and fermented were far from each other and from the volatile compounds, while the terms astringent, waxy, spicy and earthy were located closer to each other and to the volatiles. Sweet aromatic, bitter and hay were closer to 2-(dimethylamino)-3phenylbenzo[b]thiophene (cn35), ethanol (cn51) and (S)- $\Delta$-caprolactone (cn23). Throat catching was separate from all other sensory terms but closer to n-decanal (cn61), 2-hexanone (cn22), hexenal (cn64) and 2-heptanone (cn20). It is important to keep in mind that, when creating MDS maps, the mean values of the sensory measurements and actual concentration values of the analyzed volatile compounds are used as the data sets. It is well known that every aromatic compound has its own odor threshold value, though odor threshold is not directly related to that compound's present concentrations. It is defined as the concentration where the odor of the compound is perceived by 
the population or it is the lowest stimulus yielding a perceivable sensation. It is a molecular property and one aromatic may be perceivable at much lower or higher concentrations than another one (Meilgaard et al., 1991). Hence, the lack of distinct group formations for the sensory definition termsvolatile compounds on the MDS maps is expected. But still at least, the MDS maps give an idea of how these values are located in relation to each other for the poppy seed oils produced by the cold pressing technique.

It was important to observe how consumers perceived the general sensory properties of the cold pressed poppy seed oils after determining their sensory definitions and volatile profiles. The sensory terms appearance, color, odor and taste were evaluated by consumers and the results are shown in Table 4.

Most of the scores were well over 4, indicating that consumers mostly liked the oils. Generally, the odor and taste of roasted samples were more liked than the control and enzyme treated samples. On the other hand, the enzyme treated samples had lower scores for odor and taste except for the ofis 8 sample. From the results of the consumer acceptance test data (Table 4), the best three samples were selected for the consumer preference test. The selected samples were ofis 3-roasted, ofis 4-roasted and ofis 8-enzyme treated. These 3 oils were prepared as triple sets with 3 -digit number codes and served to 150 different consumers, and the percentages of consumer preference distribution are shown in Fig. 2. The ofis 4-roasted sample was the most preferred $(53.55 \%)$, followed by the ofis 3 -roasted $(36.66 \%)$ and ofis 8 -enzyme treated samples $(10.00 \%)$. Clearly it can be observed that when consumers make a purely sensorial evaluation of the samples (without any health claim or price information), they prefer roasted samples; hence, the roasting of the poppy seed results in an enhancement in total oil acceptability.

\section{CONCLUSIONS}

This study has shown that sensory descriptive terms identified for the oils of different poppy varieties were not different, but the pretreatments applied prior to cold pressing are effective in changing the sensory properties of the poppy seed oils significantly. Seed roasting was identified as the best processing operation in terms of improved sensory quality of the poppy seed oils. Poppy seed oils are mostly defined as poppy seed, hazelnut, fruity and waxy according to the sensory descriptors and as fatty, nutty, waxy, fruity, creamy, roasted and sweet according to the aromatics measured in higher abundance with their aromatic identifications, hence, poppy seed oils can be claimed as aromatic and rich edible oils. There was no clear relationship among the 12 sensory defining terms and the concentration of the measured 75 aromatic volatiles present in the oils. This is an expected situation because odor perception is associated with each aromatic compound threshold value, rather than its concentration. On the other hand, the very diverse kinds and relative abundances of the aromatic volatiles in these differently prepared cold pressed oil samples were identified in this study. Consumer tests revealed that roasted samples are more liked than other oils, and roasted yellow poppy seed (ofis4) oil was the most preferred by the consumers among the other oil samples. As a result, seed roasting prior to the cold pressing of poppy seeds can be suggested for the best sensory quality in cold press oil production.

TABLE 4. Consumer Acceptance Test Results of the Poppy seed Oils (1: dislike extremely to 5: like extremely)*

\begin{tabular}{lccccc}
\hline Sample & Treatment & Appearance & Color & Odor & Taste \\
\hline Ofis 8 (white) & Control & $3.68 \pm 0.17^{\mathrm{C}}$ & $3.70 \pm 0.17^{\mathrm{C}}$ & $3.54 \pm 0.15^{\mathrm{B}}$ & $3.38 \pm 0.16^{\mathrm{B}}$ \\
& Roasted & $4.10 \pm 0.14^{\mathrm{B}}$ & $4.04 \pm 0.15^{\mathrm{B}}$ & $4.00 \pm 0.16^{\mathrm{A}}$ & $3.98 \pm 0.14^{\mathrm{A}}$ \\
& Enzyme & $4.84 \pm 0.15^{\mathrm{A}}$ & $4.86 \pm 0.14^{\mathrm{A}}$ & $4.04 \pm 0.17^{\mathrm{A}}$ & $3.90 \pm 0.17^{\mathrm{A}}$ \\
Ofis 3 (blue) & Control & $4.66 \pm 0.11^{\mathrm{A}}$ & $4.52 \pm 0.11^{\mathrm{A}}$ & $3.70 \pm 0.12^{\mathrm{B}}$ & $3.70 \pm 0.14^{\mathrm{A}}$ \\
& Roasted & $4.70 \pm 0.11^{\mathrm{A}}$ & $4.52 \pm 0.12^{\mathrm{A}}$ & $4.11 \pm 0.14^{\mathrm{A}}$ & $4.09 \pm 0.14^{\mathrm{A}}$ \\
& Enzyme & $4.66 \pm 0.15^{\mathrm{A}}$ & $4.54 \pm 0.15^{\mathrm{A}}$ & $3.45 \pm 0.17^{\mathrm{C}}$ & $3.54 \pm 0.16^{\mathrm{B}}$ \\
Ofis 4 (yellow) & Control & $4.48 \pm 0.13^{\mathrm{B}}$ & $4.33 \pm 0.13^{\mathrm{B}}$ & $4.02 \pm 0.15^{\mathrm{B}}$ & $4.71 \pm 0.61^{\mathrm{A}}$ \\
& Roasted & $4.82 \pm 0.12^{\mathrm{A}}$ & $4.89 \pm 0.11^{\mathrm{A}}$ & $4.49 \pm 0.14^{\mathrm{A}}$ & $4.45 \pm 0.15^{\mathrm{B}}$ \\
& Enzyme & $4.39 \pm 0.15^{\mathrm{B}}$ & $4.41 \pm 0.14^{\mathrm{B}}$ & $3.98 \pm 0.17^{\mathrm{B}}$ & $3.74 \pm 0.15^{\mathrm{C}}$ \\
\hline
\end{tabular}

${ }^{*}$ The values are mean \pm standard error $(\mathrm{n}=50)$.

${ }^{\mathrm{A}-\mathrm{C}}$ Means followed by different superscript letters within each poppy seed sample represent significant differences in the treatments for the hedonic measurements. 


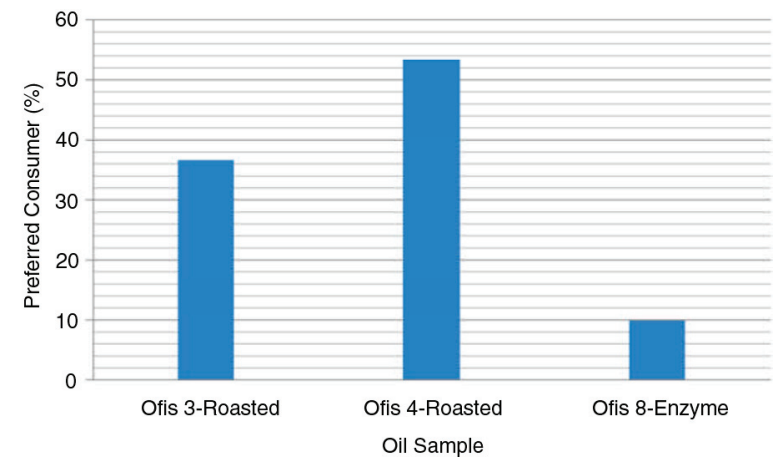

Figure 2. Consumer Preferences of the Selected Poppy seed Oil Samples $(n=150)$.

\section{ACKNOWLEDGMENTS}

This study is funded by the TUBITAK (The Scientific and Technological Research Council of Turkey) Project No: 1110618. The authors are grateful for the fund. The authors also would like to thank the panel members for their participation and input during panel training.

\section{REFERENCES}

AOCS. 1984. Method Cg 2-83. Official Methods and Recommended Practices of the American Oil Chemists Society. Champaign, Illinois, US.

Aparicio R, Morales MT, Alonso V. 1997. Autentication of European virgin olive oils by their chemical compounds, sensory attributes, and consumers' attitudes. J. Agric. Food Chem., 45, 1076-1083. http://dx.doi.org/10.1021/jf960659h

Avşar YK, Karagul-Yuceer Y, Drake MA, Singh TK, Yoon Y, Cadwallader KR. 2004. Characterization of nutty flavor in cheddar cheese. J. Dairy Sci. 87, 1999-2010. http://dx.doi. org/10.3168/jds.S0022-0302(04)70017-X

Boskou D. 1996. Olive Oil Chemistry and Technology. Champaign, Illinois, US.

Bozan B, Temelli F. 2003. Extraction of poppy seed oil using supercritical $\mathrm{CO}_{2}$. J. Food Sci. 68, 422-426. http://dx.doi. org/10.1111/j.1365-2621.2003.tb05688.x

Brühl L, Matthäus B. 2008. Sensory assessment of virgin rapeseed oils. Eur. J. Lipid Sci. Technol., 110, 608-610. http:// dx.doi.org/10.1002/ejlt.200700293

Erinç H, Tekin A, Özcan MM. 2009. Determination of fatty acid, tocopherol and phytosterol contents of the oils of various poppy (Papaver somniferum L.) seeds. Grasas Aceites 60, 375-381. http://dx.doi.org/10.3989/gya.129508

Krist S, Stuebiger G, Bail S, Unterweger H. 2006. Detection of adulteration of poppy seed oil with sunflower oil based on volatiles and triacylglycerol composition. J. Agric. Food Chem. 54, 6385-6389. http://dx.doi.org/10.1021/jf060500x

Krist S, Stuebiger G, Unterweger H, Bandion F, Buchbauer G. 2005. Analysis of volatile compounds and triglycerides of seed oils extracted from different poppy varieties (Papaversomniferum L.). J. Agric. Food Chem. 53, 83108316. http://dx.doi.org/10.1021/jf0580869

Li C, Zhao X, Chen N, Chen Y. 1990. Chemical composition of the volatile oil of papaver somniferum. Lanzhou Daxue Xuebao, Ziran Kexueban 26, 145-146.

Lyon DH, Watson MP. 1994. Sensory profilling: a method for describing the sensory charecteristics of virgin olive oil. Grasas Aceites 45, 0-25.

Martinez ML, Marcela L, Mattea MA, Maestri DM. 2008. Pressing and supercritical carbon dioxide extraction of walnut oil. J. Food Eng. 88, 399-404. http://dx.doi. org/10.1016/j.jfoodeng.2008.02.026

NIST. 2008. NIST/EPA/NIH Mass Spectral Library. National Institute of Standards and Technology Standard Reference Data Program, Gaithersburg, MD 20899.

Meilgaard M, Civille GV, Carr BT. 1991. Sensory Evaluation Techniques. CRC Press, Boca Raton, USA.

MINITAB. 2010. Minitab 16.1.1 Statistical Software. Minitab, Inc, StateCollege, Pennsylvania, USA.

Öğütçü M, Mendeş M, Yılmaz E. 2008. Sensorial and physicochemical characterization of virgin olive oils produced in çanakkale. J. Am. Oil Chem. Soc. 85, 441-456. http:// dx.doi.org/10.1007/s11746-008-1220-3

Öğütçü M, Yllmaz E. 2009. Path analysis for the behavior of traditional olive oil consumer in Çanakkale. Food Sci. Technol. Res. 15, 19-26. http://dx.doi.org/10.3136/ fstr.15.19

Özcan MM, Atalay Ç. 2006. Determination of seed and oil properties of some poppy (Papaver somniferum L.) varieties. Grasas Aceites 57, 169-174.

Pawliszyn J. 2012. Theory of solid phase microextraction. In Pawliszyn J., (Ed.) Handbook of Solid Phase Microextraction (pp.13-57). Waltham, MA, USA. http:// dx.doi.org/10.1016/B978-0-12-416017-0.00002-4

Sheskin DJ. 2004. Handbook of Parametric and Nonparametric Statistical Procedures. 3rd ed., New York, USA.

Sing J, Bargale PC. 2000. Development of a small capacity double stage compression screw press for oil expression. J. Food Eng. 43, 75-82. http://dx.doi.org/10.1016/ S0260-8774(99)00134-X.

SPSS. 1994. SPSS Professional Statistics 10.1. SPSS Inc, Chicago, IL, USA.

Wei F, Yang M, Zhou Q, Zheng C, Peng JH, Liu CS, Huang FH, Chen H. 2012. Varietal and processing effects on the volatile profile of rapeseed oils. LWT-Food Sci. Technol. 48, 323-329.

WILEY. 2005. Wiley Registry of Mass Spectral Data. 7th edition (Fred. W. McLafferty) ISBN: 978-0471473251, CD-ROM. 